\title{
Hellenistic and Roman Period Ceramic Finds from the Balatlar Church Excavations in Sinop between 2010-2012
}

\section{Eda Güngör Alper}

\section{(2) OpenEdition \\ 1 Journals}

Electronic version

URL: http://journals.openedition.org/anatoliaantiqua/289

DOI: 10.4000/anatoliaantiqua.289

\section{Publisher}

IFEA

\section{Printed version}

Date of publication: 1 January 2014

Number of pages: $35-49$

ISBN: 9782362450136

ISSN: 1018-1946

\section{Electronic reference}

Eda Güngör Alper, « Hellenistic and Roman Period Ceramic Finds from the Balatlar Church

Excavations in Sinop between 2010-2012 ", Anatolia Antiqua [Online], XXII | 2014, Online since 30 June 2018, connection on 18 December 2020. URL : http://journals.openedition.org/anatoliaantiqua/289 ;

DOI : https://doi.org/10.4000/anatoliaantiqua.289 


\section{ANATOLIA ANTIQUA ESKI ANADOLU}

\section{XXII}

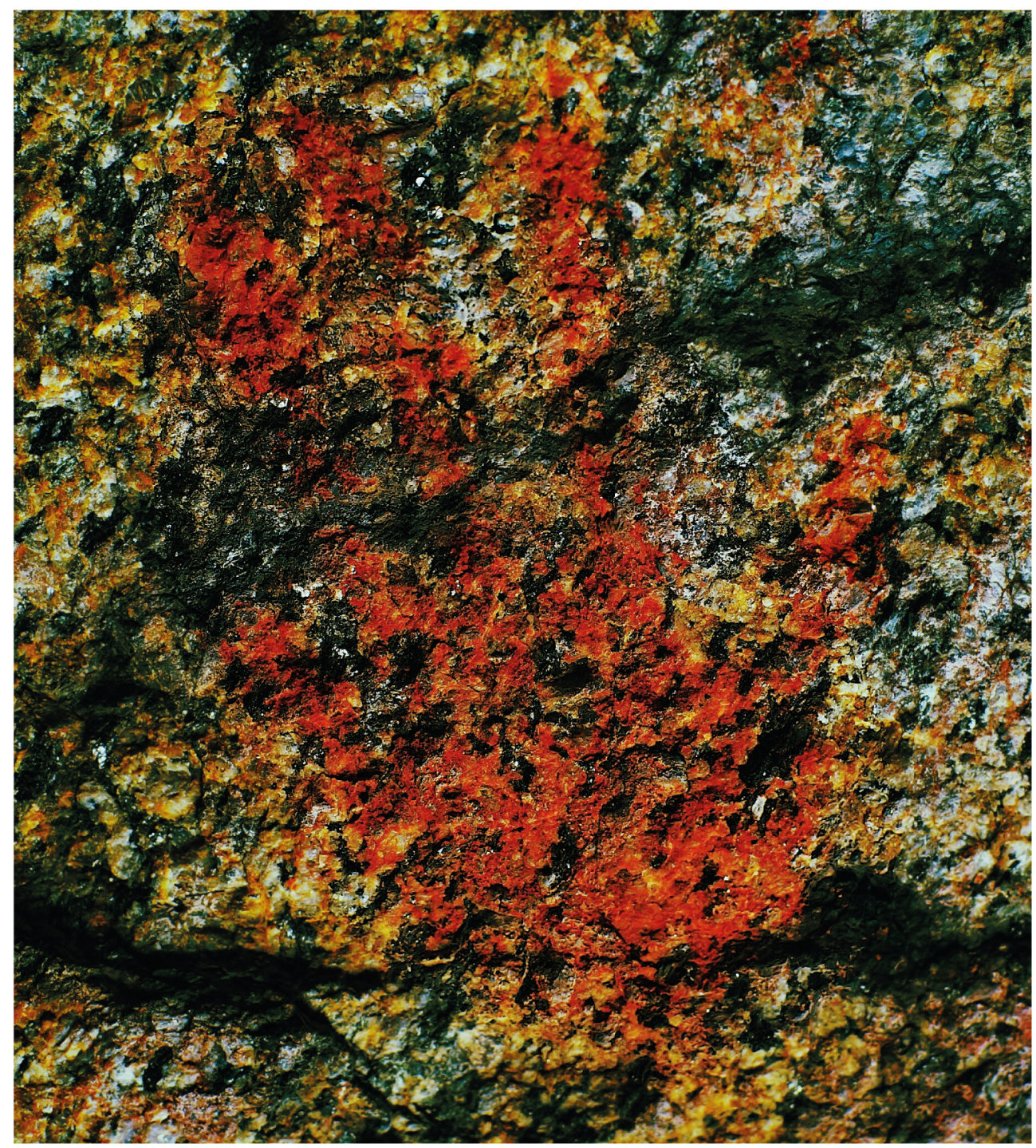

INSTITUT FRANÇAIS D'ETUDES ANATOLIENNES GEORGES-DUMEZIL CNRS USR 3131

DE BOCCARD 


\section{TABLE DES MATIERES}

Emma BAYSAL,

A preliminary typology for beads from the Neolithic and Chalcolithic levels of Barcın Höyük

William ANDERSON, Jessie BIRKETT-REES, Michelle NEGUS CLEARY,

Damjan KRSMANOVIC et Nikoloz TSKVITINIDZE,

Archaeological survey in the South Caucasus (Samtskhe-Javakheti, Georgia):

Approaches, methods and first results

Eda GÜNGÖR ALPER,

Hellenistic and Roman period ceramic finds from the Balatlar Church excavations in

Sinop between 2010-2012

Ergün LAFLI et Gülseren KAN ŞAHİN,

Hellenistic ceramics from Southwestern Paphlagonia

Oğuz TEKIN,

Weights of Lysimachea from the Tekirdağ Museum and various collections

Oğuz TEKIN,

Three weights of Lampsacus

Julie DALAISON et Fabrice DELRIEUX,

La cité de Néapolis-Néoclaudiopolis : histoire et pratiques monétaires

Martine ASSENAT et Antoine PEREZ,

Amida 4. Constance II et Amida

Sencan ALTINOLUK et Nilüfer ATAKAN,

Abrasax: A magical gem in the Istanbul Archaeological Museums

Bahadır DUMAN,

A group of local production Middle Byzantine period pottery from Tripolis:

'Micaceous White Painted Ware'

CHRONIQUES DES TRAVAUX ARCHEOLOGIQUES EN TURQUIE, 2014

Jean-Charles MORETTI,

avec la collaboration de Nicolas BRESCH, Isabel BONORA, Jean-Jacques MALMARY et

Olivier RISS,

Claros, le Temple d'Apollon : travaux réalisés en 2013

Suat ATEŞLIER,

On the excavations of the Zeus Temple of Alabanda 
Olivier HENRY,

avec Ayşe Güliz BİLGIN ALTINÖZ, Jesper BLID, Ömür Dünya ÇAKMAKLI, Andrew DUFTON, Agneta FRECCERO, Linda GOSNER, Ragnar HEDLUND, Pascal LEBOUTEILLER,

Vasilica LUNGU, Felipe ROJAS, Fredrik TOBIN, Baptiste VERGNAUD et

Andrew WATERS,

La mission Labraunda 2013 - Rapport préliminaire

Dominique BEYER, Isabelle CHALIER, Françoise KIRNER,

Françoise LAROCHE-TRAUNECKER et Aksel TIBBET,

Zeyve Höyük - Porsuk. Rapport préliminaire sur la campagne 2013

Çiğdem MANER,

Preliminary report on the first season of the Konya-Ereğli (KEYAR) survey 2013 


\section{HELLENISTIC AND ROMAN PERIOD CERAMIC FINDS FROM THE BALATLAR CHURCH EXCAVATIONS IN SINOP BETWEEN 2010-2012}

The ancient city of Sinop which was located in Paphlagonia during the Roman and Byzantine periods, is situated in the middle of the Anatolian Black Sea coast. The peninsula sheltering the city is the most northerly point of Anatolia and extends Northeastward (Fig. 1). Thanks to its localization, this area has always been an important port. History of Sinop and its environment goes back to Bronze age. Ancient sources mention that Sinop was re-founded as a Greek colony of the city of Miletus in the middle of the $7^{\text {th }}$ century B.C. ${ }^{1}$, a chronology that is confirmed by the finds from the archaeological surveys and excavations.

Besides the remains of the great city-walls ${ }^{2}$, Balatlar Church is the only building from the Roman Period in Sinop whose function could be determined. The excavations conducted by Prof. Gülgün Köroğlu since 2010 at the Balatlar Church have revealed a group of buildings that were used as a church and a graveyard from Byzantine to Ottoman periods, after being used as a bath-palaestra first ${ }^{3}$.

The first stage of the complex includes a Bath and Palaestra and is dated to Roman Imperial Period (Fig. 2-3), although the bath seems to have earlier foundation, around the $2^{\text {nd }}$ century B.C. Archaeological surveys conducted in the surroundings revealed that the complex covered a vast area. The caldarium (hot section), tepidarium (warm section), apoditerium (changing room), and palaestra (playfield) of the Bath are still preserved today.

The Hellenistic and Roman period ceramic groups retrieved from the excavations at the Balatlar Church in Sinop are fairly diverse. Although only three excavation seasons have been completed, the volume of early period information about the site continues to grow. The finds unfortunately do not provide a clear stratigraphical context, mainly because of the continuous occupation of the bath. Area I and II functioned as Eastern church, in the northeast of the cross shaped building, in the Seljuk and Ottoman Empire, between the $13^{\text {th }}$ and $15^{\text {th }}$ centuries (Fig. 2). The remains of the caldarium and the hall in the North became a cemetery that was used until the beginning of the $20^{\text {th }}$ century (Fig. 3 ).

Because Sinop is an important port city, this region was always in contact with Greek and Black Sea coasts. Therefore, Hellenistic and Roman ceramics from Balatlar Church can be compared with Greek and other ancient cities that are located on the Black Sea coast.

\section{HELLENISTIC PERIOD POTTERY FINDS}

The Hellenistic period is very well represented, from the very beginning of the period until the Roman times. The finds consist of some of the most common shapes: bowls with incurved rim, bowls with outturned rim, mould-made bowls, fish plates, kantharoi and clay lamps.

\section{Bowls with incurved rim (Pl. 1: 1-4)}

The bowls show two different shapes. The first type, bowls with incurved rim, can be dated to the $4^{\text {th }}$ century B.C. until the early $3^{\text {rd }}$ century B.C. ${ }^{4}$, although this type of bowls are known to have been used throughout the Hellenistic period. Forthcoming excavations may reveal that this shape is spread over a wider time range. As they are from the early Hellenistic period, their slips are of high quality. Some variations can be noticed in the color of the slip, prinicipally due to differences in firing the vessels.

\footnotetext{
*) Research Assistant Dr., Dokuz Eylül University, Faculty of Literature, Department of Archaeology, İzmir.

1) Drews 1976: 18.31.

2) Sinop Tarihi ve Kültür Envanteri 2013: 64.

3) Köroğlu 2011: 65-76; 2012: 313-324.

4) Histria samples: Angelescu and Baltac 2002-2003: Fig. 5 and p. 42, 87, 90, 117; Athens Agora samples: Rotroff 1997: Fig. 6263, 966-967, 980, 1000, p. 338-339; Khersonesos samples: Zolotarev 2005: Fig. 4, 8, p. 197-198.
} 


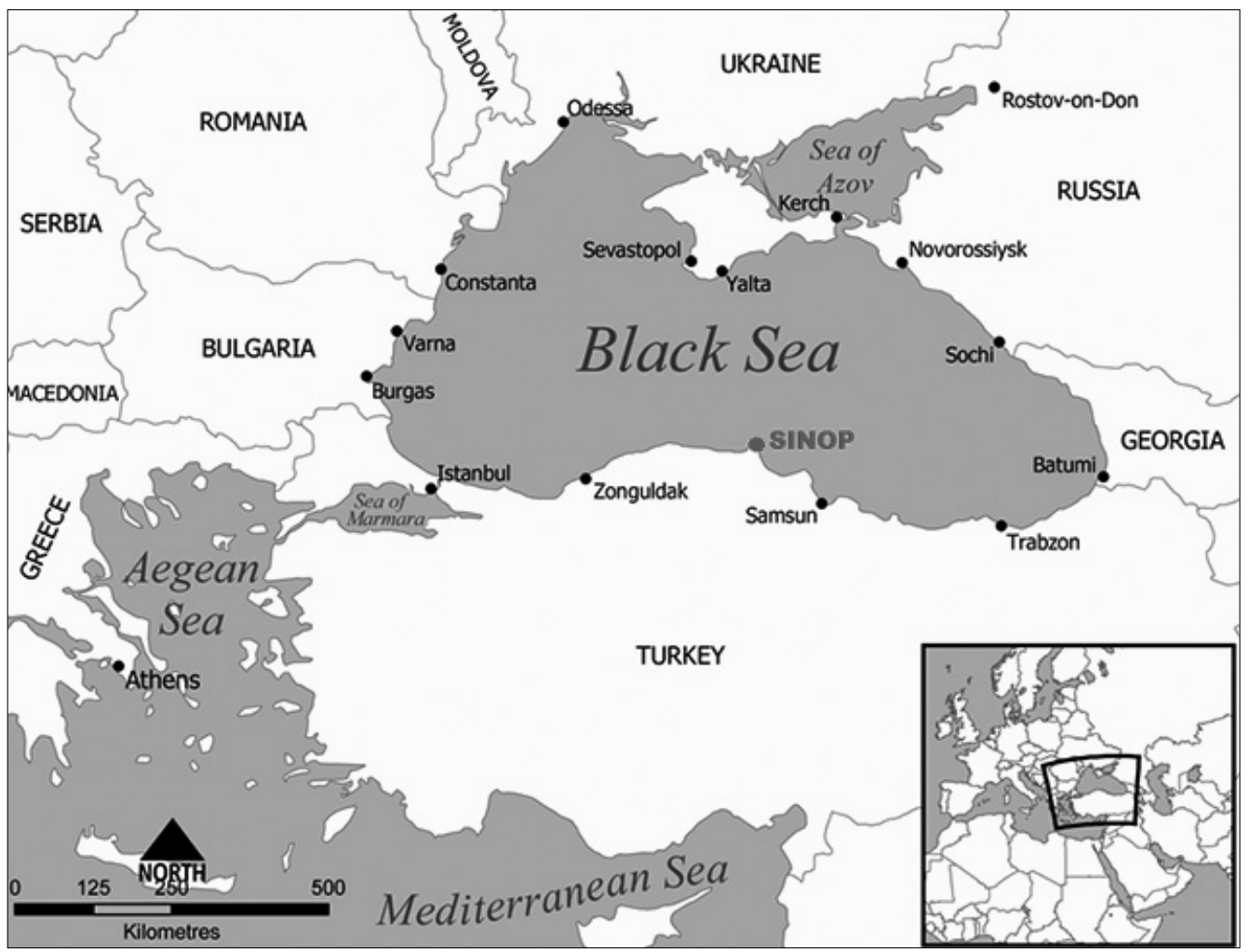

Fig. 1 : Black Sea basin and location of Sinop.

\section{SBK.2011.555}

Rim Diam.: $16 \mathrm{~cm} . \quad \mathrm{h}: 2.3 \mathrm{~cm}$.

Clay: 7.5 YR 7/4 Pink.

Temper: Calcite. Black.

Surface: inner and outer surface slip 7.5 Y 2.5/0

Similar: Angelescu and Baltac 2002-2003: Fig. 5, 42, pp. 87, 90, 117; Rotroff 1997: Fig. 62, 966, p. 338.

Date: Late $4^{\text {th }}$ century B.C.

\section{SBK.2011.602}

Rim Diam.: $15.8 \mathrm{~cm}$. h: $4 \mathrm{~cm}$.

Clay: 5 YR 6/8 Reddish yellow.

Temper: Sand.

Surface: Inner and outer 5 YR 7/6 Slip on top of reddish yellow surface $10 \mathrm{R}$ 5/8 Red.

Similar: Rotroff 1997: Fig. 62, 980, p. 339;

Zolotarev 2005: Fig. 4, 8, p. 196-197.

Date: $c a .300$ B.C.

3. SBK.2011.486

Pl. 1: 2

Rim Diam.: $9 \mathrm{~cm}$.

h: $2.1 \mathrm{~cm}$.

Clay: 7.5 YR 7/6 Reddish yellow.

Temper: Sand. Black.

Surface: Inner and outer surface slip 2.5 Y 2.5/0

Pl. 1: 1 42, p. 87, 90, 117; Rotroff 1997: Fig. 62, 976, p. 339.

Date: Early $3^{\text {rd }}$ century B.C.

4. SBK.2012.197

Pl. 1: 4

Rim Diam.: $15 \mathrm{~cm} . \quad \mathrm{h}: 3.7 \mathrm{~cm}$.

Clay: 2.5 Y 6/8 Light red.

Temper: Sand.

Surface: Inner and outer surface slip 2.5 Y 2.5/0 Black.

Similar: Rotroff 1997: Fig. 63, 1000.

Date: 290-275 B.C.

Bowls with outturned rim (P1. 1: 5-10)

Bowls with outturned rims are of a lesser quality than the previous type of bowls. They usually have a thin slip layer made of watered down clay. Black slip was used in several samples (Pl. 1: 7-8). This shape is dated to the early to middle Hellenistic period $^{5}$. In the Panskoye samples, it is mentioned that similar shapes could be identified as mortar and they are thought to be the produced in Sinop ${ }^{6}$.

5) Panskoye samples: Kašaev 2002: P1. 101, C 218, p. 159; Athens Agora samples: Rotroff 1997: Fig. 52, 59, 740, 866, p. 318, 329; Neapolis samples: Zajcev 2005: Fig. 4, 33, p. 269.

6) Kašaev 2002: 159. 

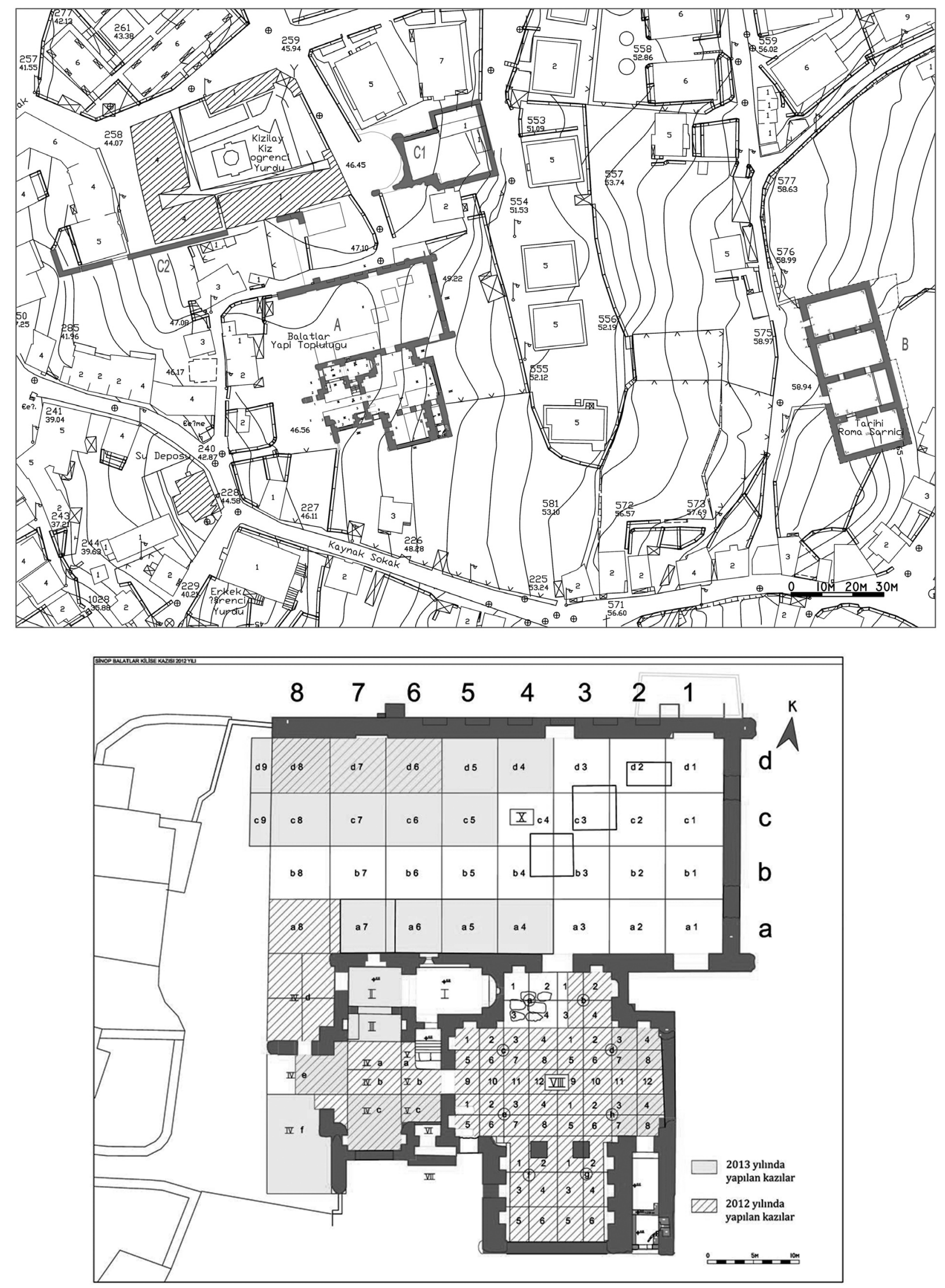

Fig. 2 : Plan of The Balatlar Bath and Palaestra Complex (Balatlar Church). 

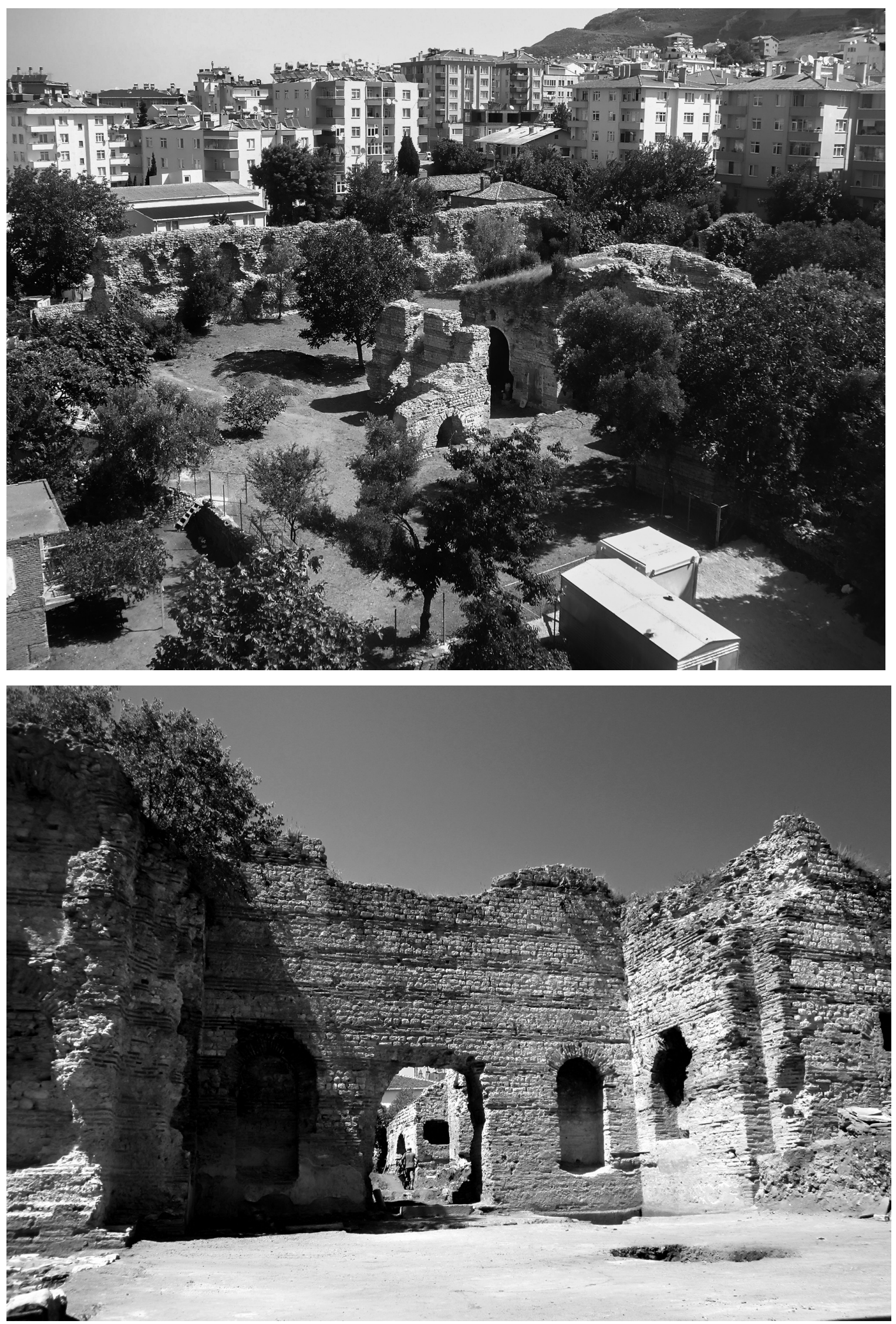

Fig. 3 : View of The Balatlar Bath and Palaestra Complex (Balatlar Church). 
PLATE 1
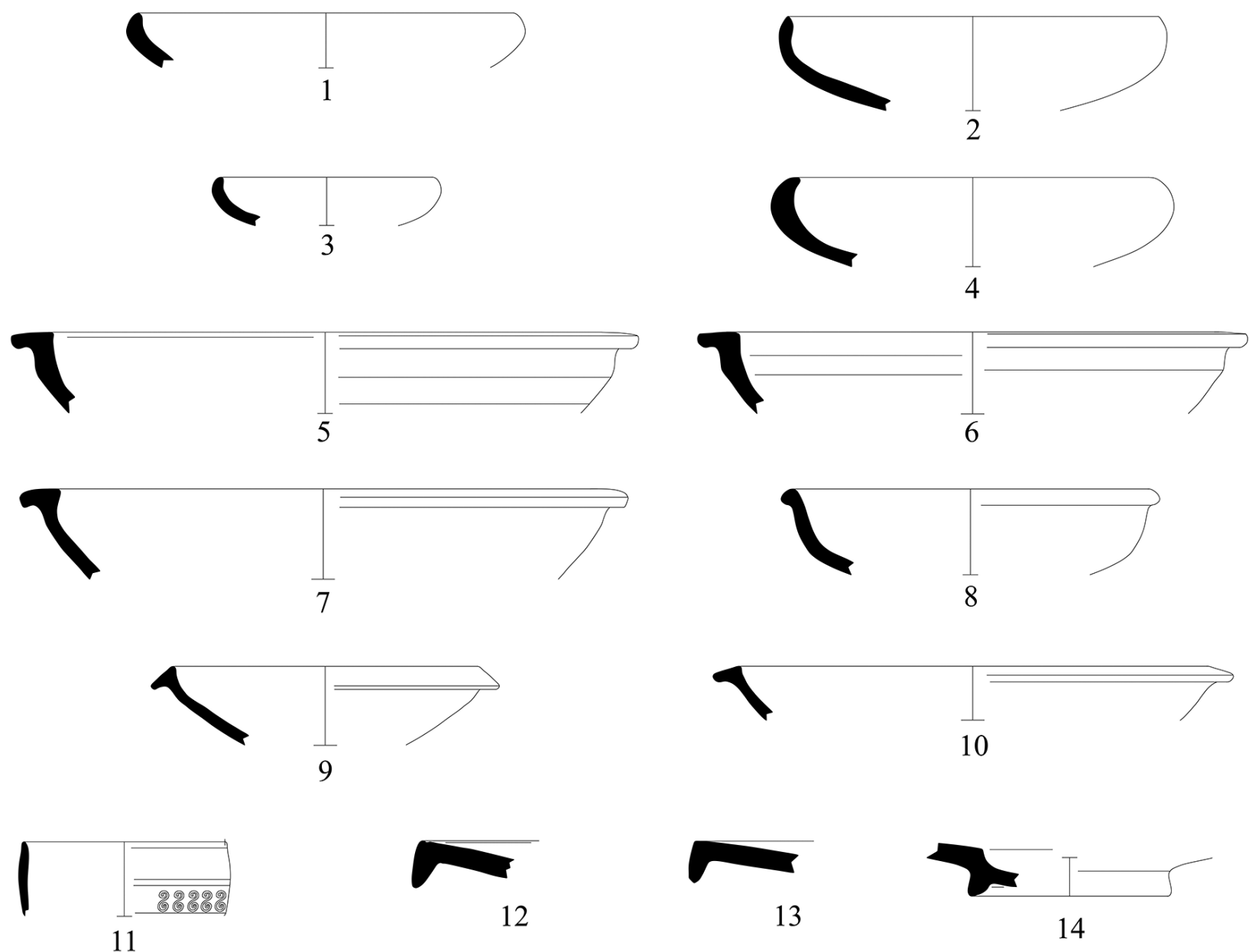

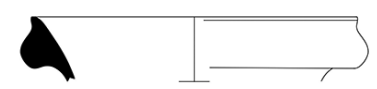

15

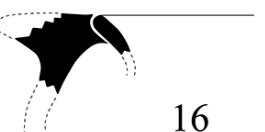

16
$1 \pi$

17

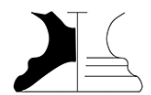

18

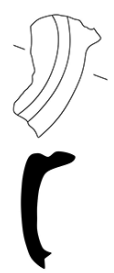

23

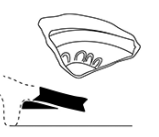

19

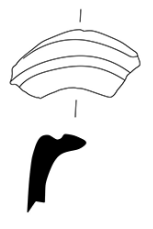

24

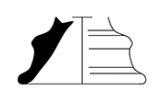

20

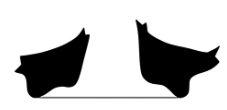

25

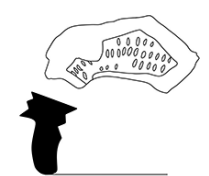

21

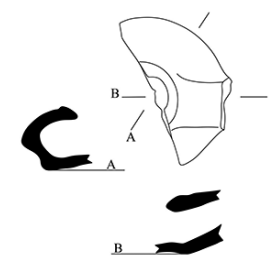

26

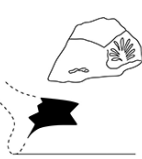

22

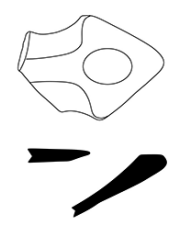

27 
5. SBK. 2011.6

Rim Diam.: $23.6 \mathrm{~cm}$. h: $3.4 \mathrm{~cm}$.

Clay: 7.5 YR 8/6 Pink.

Temper: Sand.

Surface: Inner and outer surface thin slip 7.5 YR 8/6 Pink.

Similar: Kašaev 2002: P1. 101, C 218.

Date: $4^{\text {th }}-3^{\text {rd }}$ centuries B.C.

6. SBK. 2011.6

Pl. 1: 6

Rim Diam.: $21 \mathrm{~cm} . \quad$ h: $3.4 \mathrm{~cm}$.

Clay: 7.5 YR 7/4 Pink.

Temper: Sand and Calcite.

Surface: Inner and outer surface thin slip 7.5 YR 7/4 Pembe.

Similar: Kašaev 2002: P1. 101, C 218.

Date: $4^{\text {th }}-3^{\text {rd }}$ centuries B.C.

\section{SBK.2011.6}

Pl. 1: 7

Rim Diam.: $23.4 \mathrm{~cm}$. h: $3.8 \mathrm{~cm}$.

Clay: 5 YR 6/6 Reddish yellow.

Temper: Sand and calcite.

Black.

Surface: Inner and outer surface slip 7.5 YR 7/4

Similar: Kašaev 2002: Pl. 101, C 218.

Date: $4^{\text {th }}-3^{\text {rd }}$ centuries B.C.

\section{SBK.2011.205}

Pl. 1: 8

Rim Diam.: $15.2 \mathrm{~cm}$. h: $3.7 \mathrm{~cm}$.

Clay: 7.5 YR 6/6 Reddish yellow.

Temper: Sand.

Surface: Inner and outer surface slip 5 Y 2.5/1 Black.

Similar: Rotroff 1997: Fig. 59, 866, p. 329.

Date: 325-300 B.C.

9. SBK. 2011.6

Rim Diam.: $13 \mathrm{~cm} . \quad$ h: $3.3 \mathrm{~cm}$.

Clay: 7.5 YR 7/4 Pink.

Temper: Sand and calcite. Pink.

Surface: Inner and outer surface thin slip 7.5 YR 7/4

Similar: Rotroff 1997: Fig. 52, 740, p. 318; Zajcev

2005: Fig. 4, 33, p. 269.

Date: $2^{\text {nd }}$ century B.C.

10. SBK.2011.6

Pl. 1: 10

Rim Diam.: $20 \mathrm{~cm} . \quad$ h: $2.3 \mathrm{~cm}$.

Clay: 5 YR 6/8 Pink.

Temper: Sand and calcite.

Surface: Inner and outer surface thin slip 5 YR 7/6

Reddish yellow.

Similar: Rotroff 1997: Fig. 52, 740, p. 318; Zajcev

2005: Fig. 4, 33, p. 269.

Date: $2^{\text {nd }}$ century B.C.
Mould-made bowls (P1. 1: 11)

Mould-made bowls, used throughout the Hellenistic period, have many different decorations and are hemispherical in shape. A small number of such finds were uncovered over the three-year excavation period in Sinop. These bowls are found in small numbers in other centers of the Black Sea. However it is widely used and produced in western Anatolia and the Mediterranean basin. The $2^{\text {nd }}$ century B.C. fragment has a dark grayish brown slip. Examination of other centers reveal that the slips of this bowl shape are either red or close to $\mathrm{red}^{7}$.

\section{SBK. 2012.316}

Pl. 1: 11

Rim Diam.: $8.6 \mathrm{~cm}$. h: $3.2 \mathrm{~cm}$.

Clay: HUE 10 YR 4/2 Dark grayish brown.

Temper: Calcite and mica.

Surface: Inner and outer surface slip HUE 10 YR

4/2 Dark grayish brown.

Similar: Bilde 2010, Pl. 170, F 12, p. 277.

Date: Late $2^{\text {nd }}$ century B.C.

Fish plates (Pl. 1: 12-14)

Fish plates are paeticularly common in the early Hellenistic period. An even proportion of fish plates and bowls were found during the excavations. Vessels have nearly vertical overhanging rims and a circular dimple at the center. These samples are dated to the $3^{\text {rd }}$ century B.C. ${ }^{8}$. Besides the high quality black slip ware, one of the sherds has a dark brown slip. It is understood that this shape is widely used in the Black Sea region. Although there are places where it is locally produced as red figure, black slip ware is widespread in many centers 9 .

12. SBK.2012.163

Rim Diam.: - h: $2 \mathrm{~cm}$.

Pl. 1: 12

Clay: 5 YR 6/6 Reddish yellow.

Temper: Calcite.

Surface: Inner and outer surface slip 5 YR 2.5/1 Black.

Similar: Rotroff 1997: Fig. 50, 710, p. 315.

Date: 320-310 B.C.

13. SBK.2011.613

Pl. 1: 13

Rim Diam.: $17 \mathrm{~cm} . \quad$ h: $1.8 \mathrm{~cm}$.

Clay: 5 Y 7/6 Reddish yellow.

Temper: Sand ve calcite.

Surface: Inner and outer surface slip 2.5 Y 2.5/0

Black.

Similar: Rotroff 1997: Fig. 51, 717, p. 316.

Date: $290-275$ B.C.

7) Olbia samples: Bilde 2010: Pl. 170, F 12, p. 277.

8) Athens Agora samples: Rotroff 1997: Fig. 50-51, 710, 717, p. 315-316.

9) Handberg and Petersen 2010: 236. 
14. SBK.2011.554

Foot Diam.: $8.4 \mathrm{~cm}$. h: $2.3 \mathrm{~cm}$.

Pl. 1: 14

Clay: 5 YR 5/1 Gray.

Temper: Sand.

Surface: Inner and outer surface slip 5 YR 3/2 Dark reddish brown.

Date: Late $3^{\text {rd }}$ century B.C.

Kantharoi (P1. 1: 15-17)

The kantharoi are among the highest quality tableware, especially during the early Hellenistic period. The sherds found have mainly two different shapes. The first type shows a flat rimmed while the second has a grooved rimmed. Both shapes are dated to the late $4^{\text {th }}$ century B.C. and have high quality black slips typical of the period ${ }^{10}$.

15. SBK.2011.205

Pl. 1: 15

Rim Diam.: $10.6 \mathrm{~cm}$. h: $2.1 \mathrm{~cm}$.

Clay: 5 YR 6/6 Reddish yellow.

Temper: Sand.

Surface: Inner and outer surface slip 5 YR 2.5/1 Black.

Similar: Angelescu and Baltac 2002-2003: Fig. 5, Cat. 4, p. 88; Hannestad et al. 2002: P1. 63, B 88, pp. 127-149; Rotroff 1997: Fig. 6, 36-46, p. 85.

Date: Late $4^{\text {th }}$ century B.C. $-3^{\text {rd }}$ century B.C.

16. SBK. 2010.76

Rim Diam.: - h: $2.7 \mathrm{~cm}$.

Pl. 1: 16

Clay: 5 YR 6/4 Light reddish brown.

Temper: Sand. Black.

Surface: Inner and outer surface slip 2.5 Y 2.5/0

Similar: Rotroff 1997: P1. 1, Fig. 4; Zolatarev 2005 : Fig. 5, 2-7, p. 203.

Date: Late $4^{\text {th }}$ century B.C.

17. SBK. 2010.24

Width: $2.4 \mathrm{~cm}$.

PI. 1: 17

Clay: 5 YR 7/4 Pink.

h: $2.3 \mathrm{~cm}$.

Temper: Mica.

Surface: outer surface slip 7.5 Y 2.5/0 Black, inner surface clay colored.

Date: Late $4^{\text {th }}$ century B.C.

Kantharos-Skyphos bowl feet (P1. 1: 18-22)

Among the finds, there are also basal sherds, the shapes of which cannot be fully ascertained, which we dated to the Hellenistic period based on their slips and decorations. Their shapes suggest that they are bases of kantharoi, skyphoi or bowls. There carry impressed decorations of roulettes, palmettes and ovolos in the inner faces of the bowl feet. This type of decoration is widely used in the late Classical and early Hellenistic periods. As with other shapes, black slip is used.

18. SBK.2011.502

Pl. 1: 18

Foot Diam.: $4 \mathrm{~cm}$. h: $2.6 \mathrm{~cm}$.

Clay: 5 YR 7/4 Pembe .

Temper: Sand and calcite.

Surface: Inner and outer surface slip 5 Y 4/1 Dark gray.

Date: First quarter of the $3^{\text {rd }}$ century B.C.

19. SBK.2012.354

Rim Diam.: - h: $0.7 \mathrm{~cm}$.

Pl. 1: 19

Clay: 5 YR 7/6 Reddish yellow.

Temper: Calcite and mica.

Surface: Inner and outer surface slip 5 Y 2.5/1 Black.

Similar: Handberg and Petersen 2010: P1. 100, 147, p. 210 .

Date: Early $3^{\text {rd }}$ century B.C.

20. SBK.2011.613

Pl. 1: 20

Foot Diam.: $3.9 \mathrm{~cm}$. h: $2.2 \mathrm{~cm}$.

Clay: 5 Y 7/6 Reddish yellow.

Temper: Sand. Black.

Surface: Inner and outer surface slip 2.5 Y 2.5/0

Date: Early $3^{\text {rd }}$ century B.C.

21. SBK.2011.205

Foot Diam.: - $\quad$ h: $2.7 \mathrm{~cm}$.

Pl. 1: 21

Clay: 7.5 YR 5/4 Dark brown.

Temper: Sand.

Surface: Inner and outer surface slip 5 Y 2.5/1 Black.

Date: $3^{\text {rd }}$ century B.C.

22. SBK.2011.205

Foot Diam.: - h: $1.5 \mathrm{~cm}$.

Pl. 1: 22

Clay: 7.5 YR 5/6 Dark brown.

Temper: Sand.

Surface: Inner and outer surface slip 5 Y 2.5/1 Black.

Date: $3^{\text {rd }}$ century B.C.

Oil lamps (P1. 1: 23-27)

A small number of clay lamps were found during the excavations. Most of them are black slip and wheelmade. This type of lamps are dated to the

10) Histria samples: Angelescu and Baltac 2002-2003: Fig. 5, Cat. 4, p. 88; Panskoye samples: Hannestad et al. 2002: Pl. 63, B 88, p. 127-149; Athens Agora samples: Rotroff 1997: Fig. 4, 6, 36-46, p. 85; Khersonesos samples: Zolatarev 2005: Fig. 5, 2-7, p. 203. 
early Hellenistic period ${ }^{11}$. One of the samples differs from the others with its gray slip and the fact that it is mould-made. It is known that this type of lamps are Ephesian productions. However, there are also locally produced imitations of Ephesian lamps ${ }^{12}$. It is highly likely that, as it is the sole sample, it is an imported good. Mould-made lamps started to be produced in later periods. This lamp sherd can be dated between the late $2^{\text {nd }}$ and the early $1^{\text {st }}$ centuries B.C.

23. SBK.2011.66

Length: $4 \mathrm{~cm}$.

Clay: 2.5 YR 6/8 Light red.

Temper: Sand. Black.

Surface: Inner and outer surface slip 2.5 YR 2.5/0

Similar: Howland 1958: Pl. 10, 38, 311, p. 73-74; Højte 2010: Pl. 323, O-64, p. 432.

Date: Second half of $4^{\text {th }}$ century B.C. - first quarter of the $3^{\text {rd }}$ century B.C.

\section{SBK. 2011.493}

Length: $4.8 \mathrm{~cm}$. h: $2.5 \mathrm{~cm}$.

PI. 1: 24

Clay: 2.5 YR 6/8 Light red.

Temper: Sand.

Surface: Inner and outer surface slip 7.5 YR 2.5/0 Black.

Similar: Howland 1958: Pl. 10, 38, 311.

Date: Second half of $4^{\text {th }}$ century B.C. - first quarter of the $3^{\text {rd }}$ century B.C.

\section{SBK. 2012.86}

Foot Diam.: 4.8 h: $2.5 \mathrm{~cm}$

PI. 1: 25

Clay: 5 YR 7/6 Reddish yellow.

Temper: Sand.

Surface: Inner and outer surface slip 2.5 YR 2.5/0 Black.

Date: $3^{\text {rd }}$ century B.C.

26. SBK. 2010.42

Length: $5 \mathrm{~cm}$.

Clay: 10 YR 5/3 Brown.

Temper: Calcite.

Surface: outer surface 7.5 YR 2.5/0 Black, inner surface 10 YR 6/4 Same color as the outer surface slip on top of light yellowish brown.

Similar: Howland 1958: Pl. 15, 434, p. 101-103.

Date: Late $3^{\text {rd }}$ century B.C.
27. SBK. 2012.357

Length: $4.7 \mathrm{~cm}$.

Clay: 10 YR 5/1 Gray.

Temper: Calcite.

Surface: Inner and outer surface slip 10 YR 4/1

Dark gray.

Similar: Howland 1958, Pl. 49, 666, p. 170.

Date: Late $2^{\text {nd }}$ century B.C. - early $1^{\text {st }}$ century A.D.

\section{ROMAN PERIOD POTTERY FINDS}

A large number of Roman period finds were unearthed during the 2010-12 excavation seasons. The number of finds is much larger than those dated to the Hellenistic period.

The reason for this could be that the excavation is in its early stages. In this group, high-quality forms are especially introduced. The first of these shapes is the gray slip ware, widely used in the early Roman period.

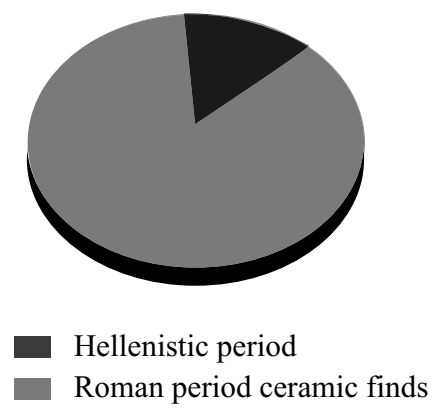

Gray slip ware (P1. 2: 28-29)

Gray slip ware can be found in many places. They are known in Antiochia, Tarsos, Samaria, Çandarl, Ephesos, Samos, Delos and Athens albeit in different shapes ${ }^{13}$. They also exist in Korinth ${ }^{14}$ and Troia $^{15}$. The latest samples from Korinth date to the reign of Tiberius ${ }^{16}$. One of the samples at the Balatlar Church in Sinop has high-quality slip and has an ovolo pattern in relief on the rim. It is a wide plate, according to the diameter of the mouth, and dates to the early $1^{\text {st }}$ century A.D. A similar sample has a yellowish red slip. As in the gray slip sample, its rim is decorated with an ovolo pattern in relief, and the contours of the shape is much softer. It is possible that the change in colour is due to firing, or that it is p. 432.

11) Athens Agora samples: Howland 1958: Pl. 10, 15, 38, 311, 434, p. 73-74, 101-103; Olbia samples: Højte 2010: Pl. 323, O-64,

12) Howland 1958: Pl. 49, 666, p. 169-170.

13) Mitsopoulos and Leon 1991: 78-85.

14) Slane Wright 1980: 135-177; Slane 1986: 271-318.

15) Hayes 1995: 185-196.

16) Slane 1980: 168. 
an imitation considering the simple changes in the shape. An identical comparative sample could not be located in other centers.

\section{SBK. 2010.76}

Pl. 2: 28

Rim Diam.: $29 \mathrm{~cm}$. h: $4.9 \mathrm{~cm}$.

Clay: 10 YR 4/1 Dark gray.

Temper: Sand.

Surface: Inner and outer surface slip 10 YR 4/1

Dark gray.

Date: Early $1^{\text {st }}$ century A.D.

29. SBK. 2010.76

Pl. 2: 29

Rim Diam.: $30 \mathrm{~cm}$. h: $3.1 \mathrm{~cm}$.

Clay: Core 2.5 YR 5/8 Light red, rims 10 YR 5/6 yellowish brown.

Temper: Sand and calcite.

Surface: Inner and outer surface slip 5 YR 5/6 Yellowish red.

Date: $6^{\text {th }}$ century A.D.

\section{Terra Sigillata (P1. 2: 30-40)}

Terra Sigilatta, often seen in this period, is frequently found at the Balatlar Church in Sinop. These simple-shaped wide plates are spread across the northeast Mediterranean and the Black Sea. Although isolated, samples were also discovered in many Black Sea settlements ${ }^{17}$.

They are defined as ESA imitation Pontic sigillata in the Black Sea basin and are dated to the $1^{\text {st }}$ century A.D. ${ }^{18}$. Similar in shape, the gray slip ware trays with thicker walls are dated to the late $1^{\text {st }}$ century A.D. The following three samples should be an imitation produced in the Black Sea basin.

\section{SBK.2011.563}

Pl. 2: 30

Rim Diam.: $19 \mathrm{~cm}$. h: $2 \mathrm{~cm}$.

Clay: Core 7.5 YR 5/2 Brown, outer side 5 YR 7/6

Reddish yellow.

Temper: Sand.

Surface: Inner and outer surface slip 10 R 4/6 Red.

Similar: Domżalski 2007: Fig. 11, a, p. 176-177;

Hayes 2008: Fig. 1, 7, 9, p. 124-125, Fig. 23, 753, p.

196; Warner Slane 1990: Fig. 11, 124, p. 60-61.

Date: $1^{\text {st }}$ century A.D.

31. SBK.2010.129

Pl. 2: 31

Rim Diam.: $20 \mathrm{~cm}$. h: $1.9 \mathrm{~cm}$.

Clay: 2.5 YR 6/4 Light brown.

Temper: Sand. Red.

Surface: Inner and outer surface slip 2.5 YR 4/8

Similar: Domżalski 2007: Fig. 11, a, p. 176-177; Hayes 2008: Fig. 1, 7, 9, p. 124-125, Fig. 23, 753, p. 196; Warner Slane 1990: Fig. 11, 124, p. 60-61.

Date: $1^{\text {st }}$ century A.D.

32. SBK. 2011.6

Pl. 2: 32

Rim Diam.: $30.8 \mathrm{~cm}$. h: $2.2 \mathrm{~cm}$.

Clay: Core 2.5 Y 4/0 Pink, outer side 7.5 YR 7/4 Pink.

Temper: Sand.

Surface: Inner and outer surface slip $10 \mathrm{R}$ 4/8 Red.

Similar: Hayes 2008: Fig. 29, 905, pp. 212-213.

Date: Late $1^{\text {st }}$ century B.C.

Plates with a vertical rim (Pl. 2: 33-35), widespread in the Black Sea basin, are among the Pontic sigillata $^{19}$. The number of plates are of similar proportions to sherds of other shapes. This plates have got angled and raised rim. Sigillata of this form are dated to the $1^{\text {st }}$ century A.D. ${ }^{20}$.

33. SBK. 2010.41

Pl. 2: 33

Rim Diam.: $25.6 \mathrm{~cm}$. h: $3.5 \mathrm{~cm}$.

Clay: 7.5 YR 7/6 Reddish yellow.

Temper: Sand.

Surface: Inner and outer surface slip 2.5 YR 4/8

Red, surfaces are very eroded.

Similar: Zhuravlev 2009: Fig. 3, Form 2, 19, pp. 3435; Laflı and Kan Sahin 2012: p. 58-59.

Date: $1^{\text {st }}$ century A.D.

34. SBK.2012.220

Rim Diam.: $\quad$ h: $2.3 \mathrm{~cm}$.

Pl. 2: 34

Clay: 2.5 YR 6/8 Light red.

Temper: Sand and calcite.

Surface: Inner and outer surface slip 2.5 YR 4/8 Red. 35.

Similar: Zhuravlev 2009: Fig. 3, Form 2, 18, p. 34-

Date: $1^{\text {st }}$ century A.D.

35. SBK. 2011.565

Pl. 2: 35

Rim Diam.: $24 \mathrm{~cm} . \quad \mathrm{h}: 2.4 \mathrm{~cm}$.

Clay: 7.5 YR 7/4 Light red.

Temper: Sand.

Surface: Inner and outer surface slip 10 R 4/4 Red.

Similar: Zhuravlev 2009, Fig. 5, Form 3, 5, p. 39.

Date: Late $1^{\text {st }}$ century A.D.

17) Domżalski 2007: 176.

18) Phanagoria samples: Domżalski 2007: Fig. 11, a, p. 176-177; Athens Agora samples: Hayes 2008: Fig. 1, 23, 29, 7, 9, 753, 905, p. 124-125, 196, 212-213; Korinth samples: Warner Slane 1990: Fig. 11, 124, p. 60-61.

19) Zhuravlev 2009: 25.

20) Belbek samples: Zhuravlev 2009: Fig. 3, 5, Form 2, 3, 5, 18, 19, p. 34-35, 39. 
PLATE 2
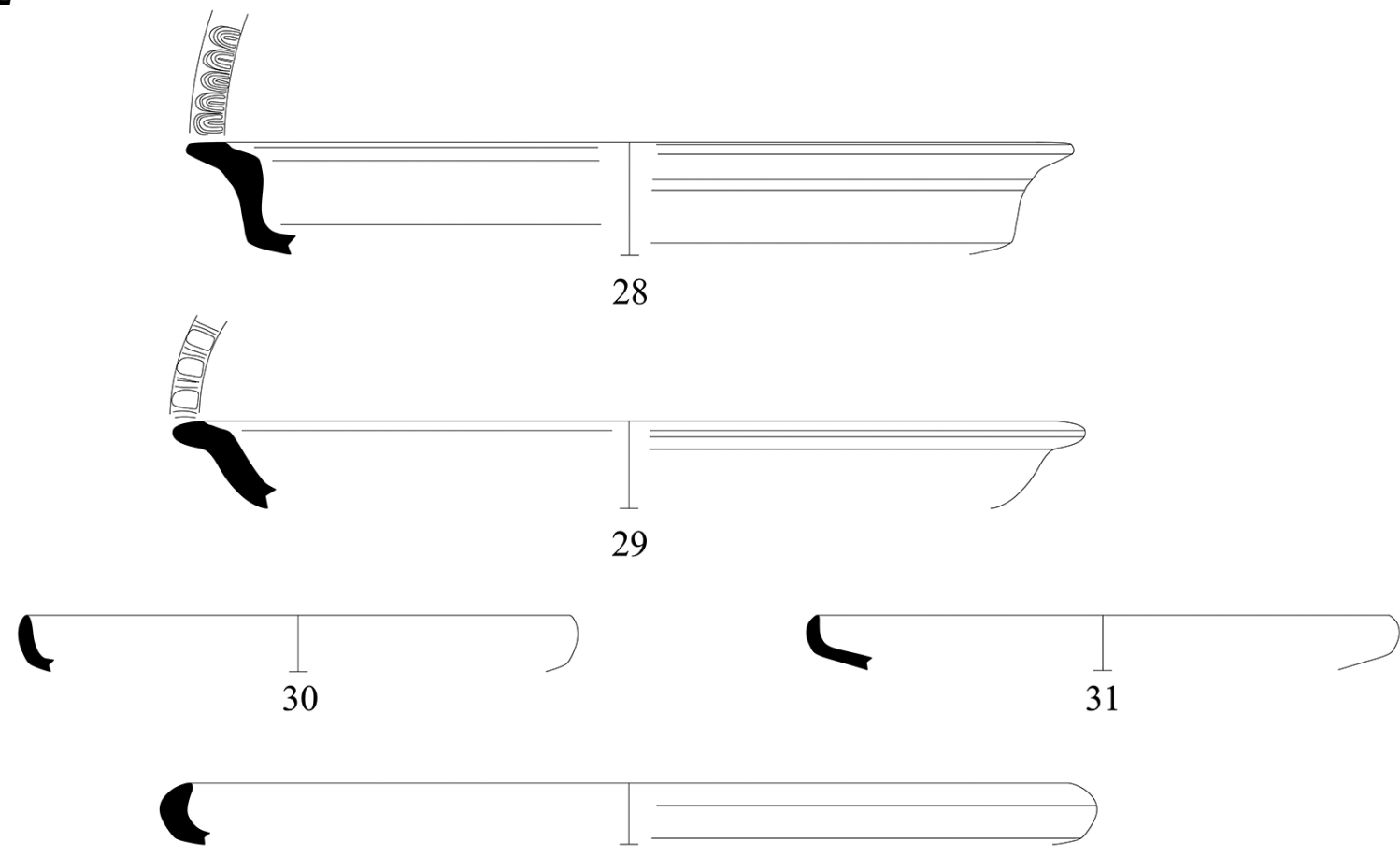

32

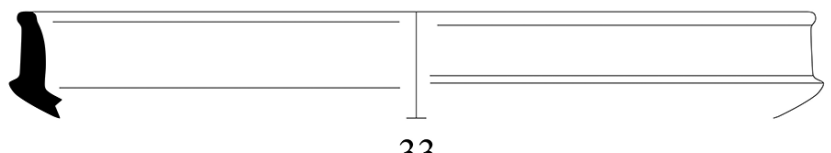

33

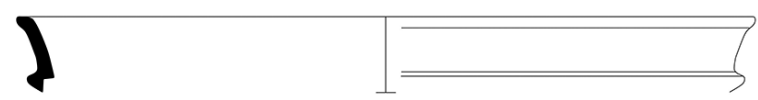

35

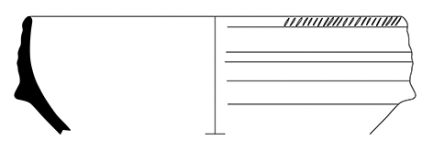

37

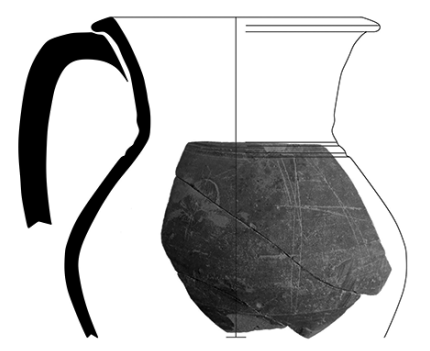

39

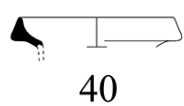

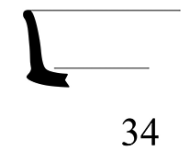

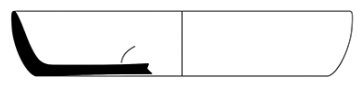

36

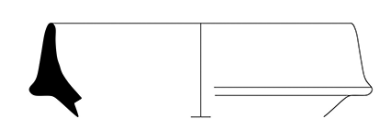

38

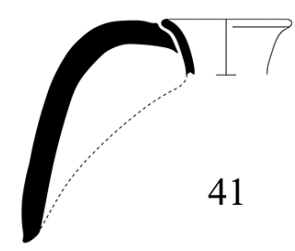

41

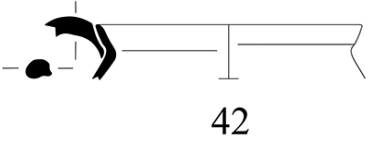


Another plate shape is the flat based (P1. 2: 36), thin and elegant walled, glossy slip sigillata. Its small mouth diameter is striking. The mouth diameters of this shape of vessels are usually wider. Considering its shape and slip characteristics, it could be an ESB imitation. It is known that this shape is an Anatolian production ${ }^{21}$. The shape, as in the plates with vertical rims, dates to the $1^{\text {st }}$ century A.D. ${ }^{22}$.

36. SBK.2012.124-186

Rim Diam.: $11 \mathrm{~cm}$.

Clay: 2.5 YR 6/8 Light red.

Temper: Calcite. Red.

Surface: Inner and outer surface slip 2.5 YR 5/8

Similar: Hayes 1973: Pl. 87, 151, p. 455; Krapivina 2010: Pl. 163, E-52, p. 266.

Date: $1^{\text {st }}$ century A.D.

One of the most common bowl shapes is the thin, grooved rim bowls (Pl. 2: 37). This sherd has incised transverse lines on a grooved rim. They date to a later period, ca. $2^{\text {nd }}-3^{\text {rd }}$ centuries A.D. ${ }^{23}$.

37. SBK.2012.224

PI. 2: 37

Rim Diam.: $12.2 \mathrm{~cm}$. h: $3.7 \mathrm{~cm}$.

Clay: 5 YR 7/4 Pink.

Temper: Calcite and mica. Red.

Surface: Inner and outer surface slip 2.5 YR 4/8

Similar: Hayes 1973: Pl. 91, 220, p. 465-466.

Date: $2^{\text {nd }}$ century A.D.

The last bowl shape is the typical ESC (Pl. 2: 38). This shape is known to be the production of Çandarl 1 and is found in many settlements along the Black Sea coast ${ }^{24}$. The upper part protruding from below the rim is hemispherical in shape. The upper body of the sherd, dated to the first half of the $2^{\text {nd }}$ century A.D. ${ }^{25}$, is missing.

38. SBK. 2012.356

Rim Diam.: $9.8 \mathrm{~cm}$. h: $3.1 \mathrm{~cm}$.

Pl. 2: 38

Clay: 5 YR 8/4 Pink.

Temper: Sand and calcite. Red.
Similar: Hayes 2008: Fig. 25, 794, p. 200; Zhuravlev 2002: Fig. 4, 3, p. 246.

Date: First half of the $2^{\text {nd }}$ century A.D.

Jugs (P1. 2: 30-40) are obtained in two different shapes - the rims of both make a triangular projection extending outwards from the rim. However, in one of the samples, the rim is more vertical and the transition to the body offers a wider curve. There is an incised letter 'A' on another thicker walled jug. These marks can be considered as potters' marks.

39. SBK.2011.205

Pl. 2: 39

Rim Diam.: $8.2 \mathrm{~cm} . \quad$ h: $10.4 \mathrm{~cm}$.

Clay: 5 YR 6/6 Reddish yellow.

Temper: Sand and mica.

Surface: Inner surface slip 5 YR 5/6 Red and outer surface slip 2.5 YR 5/8 Red. Incised letter 'A' on the body.

Date: $1^{\text {st }} 2^{\text {nd }}$ centuries A.D.

40. SBK.2011.555

Rim Diam.: $5 \mathrm{~cm}$. h: $1 \mathrm{~cm}$.

Clay: 2.5 YR 5/8 Red.

Temper: Sand, mica.

Surface: Inner and outer surface slip 2.5 YR 4/8 Red.

Date: $1^{\text {st }}-2^{\text {nd }}$ century A.D.

Thin-walled ware (P1. 2: 41-42)

Thin-walled jugs and mugs have been widespread in all centers dominated by Roman empire since the early Roman period. This group of vessels, abundant in eastern Mediterranean, Italy and eastern Europe, can be distinguished through its thin walls. However, it shares its decoration features with other vessel shapes. The thin walls and decoration types suggest that they are made in imitation of metal vessels ${ }^{26}$. The sherds discovered during the excavations at the Balatlar Church in Sinop are fragments of jugs and mugs. The rim and handle of a small-sized jug was also retrieved. This sample dates to the first half of the $2^{\text {nd }}$ century A.D. Among the more widely encountered jugs, one of the sherds, which dates to the $2^{\text {nd }}$ century - mid $3^{\text {rd }}$ century A.D., has its rim and a small part of the handle ${ }^{27}$.

21) Krapivina 2010: 266.

22) Korinth samples: Hayes 1973: Pl. 87, 151, p. 455; Olbia samples: Krapivina 2010: Pl. 163, E-52, p. 266.

23) Korinth samples: Hayes 1973: Pl. 91, 220, p. 465-466.

24) Zhuravlev 2002: 245.

25) Neapolis, Tanais, Myrmekion samples: Zhuravlev 2002: Fig. 4, 3, p. 246.

26) Anderson-Stojanovic 1992: 35-36; Hayes 1997: 96; Riley 1979: Fig. 104, 520.

27) Athens Agora samples: Hayes 2008: Fig. 50-51, 1603, 1608, p. 267-268 
41. SBK.2011.460

Rim Diam.: $4 \mathrm{~cm}$. h: $7.7 \mathrm{~cm}$.

PI. 2: 41

Clay: 7.5 YR 7/6 Reddish yellow.

Temper: Sand.

Surface: Inner ve outer surface 10 YR 3/1 Dark gray.

Similar: Hayes 2008: Fig. 50, 1603, p. 267.

Date: First half of the $2^{\text {nd }}$ century A.D.

42. SBK.2012.224

Rim Diam.: $8.6 \mathrm{~cm}$. h: $1.8 \mathrm{~cm}$.

PI. 2: 42

Clay: 2.5 YR 5/8 Red.

Temper: Calcite.

Surface: Inner and outer surface thin slip 5 YR 4/1 Dark gray.

Similar: Hayes 2008: Fig. 51, 1608, p. 268.

Date: $2^{\text {nd }}$ century A.D. - mid $3^{\text {rd }}$ century A.D.

\section{LATE ROMAN PERIOD POTTERY FINDS}

The Bath and palaestra complex which is dated to the Roman period, has been used as a Church in the Late Roman Period, that is why ceramic finds belonging to Late Roman period are also found in large numbers. Red slip ware forms and clay lamps have a significant place among the other pottery finds.

\section{Red Slip Ware (Pl. 3: 43-54)}

The high-quality sigillata slips were replaced with matt slips of lesser quality starting from the Late Roman period. The same forms continue to be used. The 'Late Roman Red Slip Ware' contains a diverse set of vessel shapes. This group of wares is especially abundant among the finds. They are found over a long timespan, from the $4^{\text {th }}$ until the $7^{\text {th }}$ century A.D.

In the first sample of the deep plates (P1. 3: 43), it can be seen that the rim is jutted to receive the lid. Below the jut, there are incised lines with wide spaces left in between. There are approximately seven rows of impressed decorations of small roulette patterns. Roulette decorations are very widespread in this period. Similar sherds to this $4^{\text {th }}$ century A.D. sherd were discovered during the Demirci amphora workshop excavations near Sinop ${ }^{28}$.

43. SBK. 2011.563

Rim Diam.:h: $4.6 \mathrm{~cm}$.

Pl. 3: 43

Clay: 5 YR 5/8 Yellowish red.

Temper: Sand and calcite.
Surface: Inner surface slip 2.5 YR 5/4 Reddish brown and outer surface slip 2.5 YR 5/8 Red.

Similar: Kassab Tezgör 2010: Pl. 53, Cat. 37, p. 194

Date: $4^{\text {th }}$ century A.D.

Among the deep plates, the group with flat rims (P1. 3: 44-47), which make a sharp turn in the transition to the body, dated to the late $4^{\text {th }}$ - early $5^{\text {th }}$ century A.D. ${ }^{29}$, is the most common group. There is no footed sample among this wide mouth plates. However, when compared with similar samples ${ }^{30}$, it can be seen that this type of plates are low footed.

44. SBK.2011.433

Pl. 3: 44

Rim Diam.: $21.6 \mathrm{~cm}$. h: $3.7 \mathrm{~cm}$.

Clay: 2.5 YR 6/8 Light red.

Temper: Sand.

Surface: Inner and outer surface slip 2.5 YR 5/8 Red.

Similar: Hayes 1972: Fig. 65, 1, p. 325; Kassab

Tezgör 2010: Pl. 50, Cat. 11, 190.

Date: Late $4^{\text {th }}$ - early $5^{\text {th }}$ century A.D.

45. SBK. 2012.460

Pl. 3: 45

Rim Diam.: $18.2 \mathrm{~cm}$. h: $2.8 \mathrm{~cm}$.

Clay: 7.5 YR 7/4 Pink.

Temper: Calcite.

Surface: Inner and outer surface slip 10 R 4/8 Red.

Similar: Hayes 1972: Fig. 65, 1, p. 325; Kassab

Tezgör 2010: Pl. 50, Cat. 11, 190.

Date: Late $4^{\text {th }}$ - early $5^{\text {th }}$ century A.D.

46. SBK.2011.596

Pl. 3: 46

Rim Diam.: $19.2 \mathrm{~cm}$. h: $3.2 \mathrm{~cm}$.

Clay: 7.5 YR 7/4 Pink.

Temper: Sand.

Surface: Inner and outer surface slip 2.5 YR 4/6 Red.

Similar: Hayes 1972: Fig. 65, 1, p. 325; Kassab

Tezgör 2010: Pl. 50, Cat. 11, 190.

Date: Late $4^{\text {th }}$ century A.D. - early $5^{\text {th }}$ century A.D.

47. SBK.2011.596

Pl. 3: 47

Rim Diam.: $21.2 \mathrm{~cm} . \mathrm{h}: 2.8 \mathrm{~cm}$.

Clay: 7.5 YR 7/4 Pink.

Temper: Sand.

Surface: Inner and outer surface slip 2.5 YR 5/8 Red.

Similar: Hayes 1972, Fig. 65, 1, p. 325; Kassab

Tezgör 2010, Pl. 50, Cat. 11, 190.

Date: Late $4^{\text {th }}$ century A.D. - early $5^{\text {th }}$ century A.D. 
PLATE 3

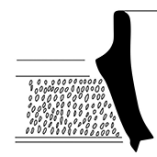

43
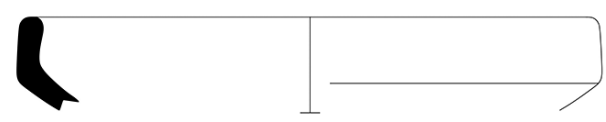

45

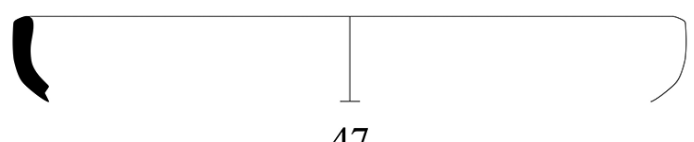

47
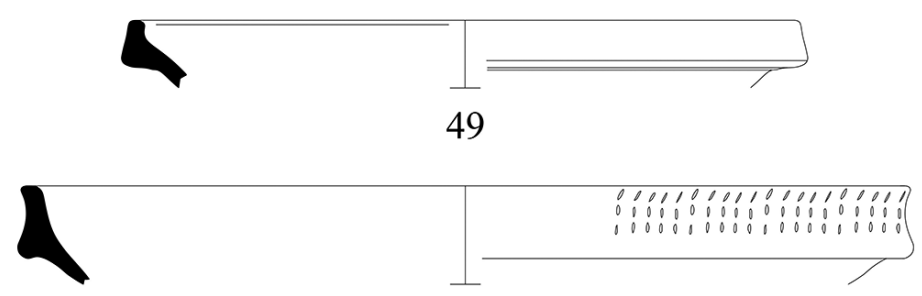

50

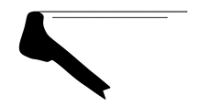

51

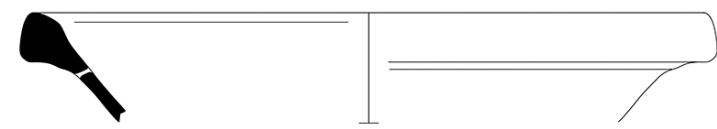

53
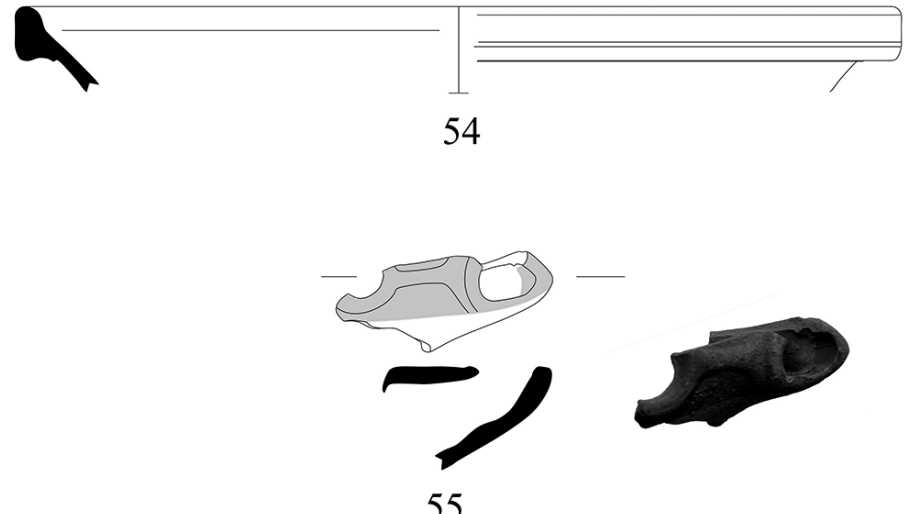

55

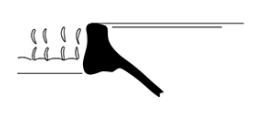

52 
The most common shape among the 'Late Roman Red Slip Ware' is the similarly rimmed wide bowls and plates. In this type of vessels (P1. 3: 48-54), the rim usually jutts outwards and makes a groove where it joins the body. The body then narrows towards the foot. In some of the sherds, there are two or three rows of roulette decorations on the rims. There is a small hole in the body of one of the sherds. This hole is most likely a repair mark. This shape, based on similar vessels, can be dated to the $5^{\text {th }}-6^{\text {th }}$ century A.D ${ }^{31}$.

48. SBK.2011.205

Rim Diam.: $18 \mathrm{~cm}$.

Clay: 10 R 5/8 Red.

Temper: Sand.

Surface: Inner and outer surface slip 10 R 5/8 Red.

Similar: Hayes 1972: Fig. 68, 10, p. 337; Kassab

Tezgör 2010: Pl. 51, Cat. 21, p.191.

Date: $5^{\text {th }}$ century A.D.

49. SBK.2011.6

PI. 3: 49

Rim Diam.: $21.6 \mathrm{~cm}$. h: $2.3 \mathrm{~cm}$.

Clay: 2.5 YR 5/8 Red .

Temper: Sand and calcite. Red.

Surface: Inner and outer surface slip 2.5 YR 5/8

Similar: Hayes 1972: Fig. 68, 10, p. 337; Kassab Tezgör 2010: Pl. 51, Cat. 18, p.191.

Date: $5^{\text {th }}$ century A.D.

50. SBK. 2011.606

Rim Diam.: 28.8 cm. h: $3.2 \mathrm{~cm}$.

Pl. 3: 50

Clay: $10 \mathrm{R}$ 6/6 Red .

Temper: Calcite.

Surface: Inner and outer surface slip $10 \mathrm{R}$ 6/6 Red.

Similar: Hayes 1972: Fig. 68, 14, p. 337; Kassab

Tezgör 2010: Pl. 51, Cat. 18, p.191.

Date: $5^{\text {th }}$ century A.D.

51. SBK.2011.205

Rim Diam.: -

h: $2.8 \mathrm{~cm}$.

Clay: 10 R 4/8 Red.

Temper: Calcite.

Surface: Inner and outer surface slip 10 R 5/6 Red.

Similar: Hayes 1972: Fig. 68, 14, p. 337; Kassab

Tezgör 2010: Pl. 51, Cat. 18, p.191.

Date: $5^{\text {th }}$ century A.D.

52. SBK.2011.6

Rim Diam.:- h: $2.4 \mathrm{~cm}$.

Pl. 3: 52

Clay: 2.5 YR 5/8 Red.

Temper: Sand and calcite. Red.

Surface: Inner and outer surface slip 2.5 YR 5/8

Similar: Hayes 1972: Fig. 68, 16, p. 337; Kassab

Tezgör 2010: Pl. 51, Cat. 23, p.192.

Date: Late $5^{\text {th }}$ - early $6^{\text {th }}$ century A.D.

53. SBK.2011.255

Rim Diam.: $22 \mathrm{~cm}$. h: $3.6 \mathrm{~cm}$.

PI. 3: 53

Clay: 2.5 YR 6/8 Açık red.

Temper: Sand, mica and calcite. Red.

Surface: Inner and outer surface slip 2.5 YR 5/8

Similar: Domzalski 2011: Fig. 10-11, Fig. 3, 2. 10; Hayes 1972: Fig. 71, 4.

Date: $6^{\text {th }}$ century A.D.

54. SBK.2011.205

PI. 3: 54

Rim Diam.: 28.4 cm. h: $2.8 \mathrm{~cm}$.

Clay: 2.5 YR 4/6 Red.

Temper: Calcite.

Surface: Inner and outer surface slip 2.5 YR 5/6

Red. Burn mark on rim. 193.

Similar: Kassab Tezgör 2010: Pl. 52, Cat. 34, p.

Date: $6^{\text {th }}$ century A.D.

\section{Oil Lamp (Pl. 3: 55)}

One late Roman clay lamp was discovered (Pl. 3: 55). The lamp, the spout and body of which was preserved, has its upper body decorated with poured reddish yellow paint on top of a thin beige colored slip. The embossed projection around the discus joins with the edge of the nozzle. The lamp fragment can be dated to the $6^{\text {th }}-7^{\text {th }}$ centuries A.D. based on the width of the discus hole and the shape of the nozzle.

55. SBK.2011.135

Length: $7.1 \mathrm{~cm}$.

Clay: 7.5 YR 7/4 Pink.

Temper: Sand, calcite, mica and shamotte.

Surface: Inner and outer surface 5 YR 6/8 Reddish yellow on top of clay paint color.

Date: $6^{\text {th }}-7^{\text {th }}$ centuries A.D.

\section{CONCLUSIONS}

It is too early to draw conclusions from the finds of the excavations at the Balatlar Church in Sinop, considering that only the third season has been completed yet. However, based on these finds, 
it can be said that, typical shapes of the period exist here, as in other settlements across the Black Sea. On the other hand, while some Hellenistic shapes of high-quality black slip ware are considered to be imported, various Roman period shapes could be local. Although the pottery workshops around Sinop are from an earlier period, their existence support this hypothesis. It is not surprising for a port city like Sinop for various sigillata shapes of the Black Sea to be discovered here. It is presumed that, forthcoming excavations will reveal more detailed proofs.

E.G.A.

\section{ABBREVIATIONS AND REFERENCES}

Anderson-Stojanovic, V.R., 1992: Stobi, The Hellenistic and Roman Pottery, Princeton.

Angelescu, A.V. and Bâltâc, A., 2002-2003: "Sondajul ' $\alpha$ ' din basilica episcopală de la Histria', Pontika 35-36: 85-123.

Bilde, P.G., 2010: "Mouldmade Bowls”, in Lejpunskaja, Nina A. et al. (eds.), The Lower City of Olbia, (Sector $N G S)$, in the $6^{\text {th }}$ Century B.C. to the $4^{\text {th }}$ Century AD, Vol. 1 [Black Sea Studies 13], Aarhus: 269-288.

Domżalski, K., 2007: "Changes in Late Classical and Hellenistic Fine Pottery Production in Eastern Mediterranean as Reflected by Imports in the Pontic Area", in Gabrielsen, V. and Lund, J. (eds.), Black Sea in Antiquity: Regional and Interregional Economic Exchanges [Black Sea Studies 6], Aarhus: 161-182.

- 2011: "Late Roman Pottery from Pompeiopolis", in Summerer, L. (ed.), Pompeiopolis I: eine Zwischenbilanz aus der Metropole Paphlagoniens nach fünf Kampagnen (2006-2010) [Schriften des Zentrums für Archäologie und Kulturgeschichte des Schwarzmeerraumes, Bd 21]: 163-178.

Drews, R., 1976: "The Earliest Greek Settlements on the Black Sea", Journal of Hellenic Studies 96: 18-31.

Handberg, S. and Petersen, J.H., 2010: "Glossed Pottery", in Lejpunskaja, Nina A. et al. (eds.), The Lower City of Olbia, (Sector NGS), in the 6th Century B.C. to the 4th Century AD, Vol. 1 [Black Sea Studies 13], Aarhus: 185-260.

Hannestad, L., Stolba, V.F. and Blinkenberg Hastrup, H., 2002: "Black-Glazed Pottery, Red-Figure and grey Ware Pottery", in Hannestad, L., Stolba, V.F. and Shcheglov, A.N. (eds.), Panskoye I, The Monumental Building U6, Aarhus: 127-149.

Hayes, J.W., 1973: "Roman Pottery from the South Stoa at Corinth", Hesperia 42.4: 416-470.

- 1995: "An Early Roman Well Group from the Troia Excavations 1992”, Studia Troica 5: 185-196.

- 1997: Handbook of Mediterranean Roman Pottery, University of Oklahoma Press.

- 2008: Roman Pottery, Fine Ware Imports [The Athenian Agora, Vol. XXXII], Princeton.

Højte, J.M., 2010: "Lamps", in Lejpunskaja, Nina A. et al. (eds.), The Lower City of Olbia, (Sector NGS), in the $6^{\text {th }}$ Century B.C. to the $4^{\text {th }}$ Century AD, Vol. 1 [Black Sea Studies 13], Aarhus: 423-438.
Howland, R.H., 1958: Greek Lamps and Their Survivals [The Athenian Agora, Vol. IV], Princeton.

Kašaev, S.V., 2002: "Commonware", in Hannestad, L., Stolba, V.F. and Shcheglov, A.N. (eds.), Panskoye I, The Monumental Building U6, Aarhus: 150-179.

Köroğlu, G., 2011: "2010 Yılı Sinop Balatlar Kilisesi Kazıs1", KST 33: 65-76.

- 2012: "Sinop Balatlar Kilisesi 2011 Yılı Kazı Çalışmaları", KST 34: 313-324.

Krapivina, V.V., 2010: "Red Glossed Pottery", in Lejpunskaja, Nina A. et al. (eds.), The Lower City of Olbia, (Sector NGS), in the $6^{\text {th }}$ Century B.C. to the $4^{\text {th }}$ Century AD, Vol. 1 [Black Sea Studies 13], Aarhus: 261268.

Laflı, E. and Kan Şahin, G., 2012: "Terra Sigillata and Red-Slipped Ware from Hadrianopolis", Anatolia Antiqua XX: 45-120.

Riley, J.A., 1979: "The Coarse Pottery from Benghazi”, in Lloyd, J.A. (ed.), Excavations at Sidi Khrebish Benghazi (Berenice), vol. 2, Tripoli: 91-467.

T.C. Sinop İl Özel İdaresi, Sinop Tarihi ve Kültür Envanteri, 2013.

Slane Wright, K.A., 1980: "Tiberian Pottery Deposit from Corinth", Hesperia 49.5: 135-177.

- 1986: "Two Deposits from the Early Roman Cellar Building", Hesperia 55.3: 271-318.

Warner Slane, K., 1990: Corinth XVIII.2, The Sanctuary of Demeter and Kore: The Roman Pottery and Roman Lamps, Princeton.

Zajcev, J.P., 2005: "Absolute and Relative Scythian Neapolis in the $2^{\text {nd }}$ century B.C.", in Stolba, V.F. and Hannestad, L. (eds.), Chronologies of the Black Sea Area in the Period c. 400-100 B.C., Aarhus: 259-275.

Zolotarev, M. I., 2005: "The Hellenistic Ceramic Deposit from the North-eastern Sector of Chersonesos", in Stolba, V.F. and Hannestad, L. (eds.), Chronologies of the Black Sea Area in the Period c. 400-100 B.C., Aarhus: 193-216.

Zhuravlev, D.V., 2002: “Terra Sigillata and Red Slip Pottery in the North Pontic Region (A Shorth Bibliographical Survey)", Ancient Civilizations 8, 3-4: 237-309.

- 2009: "Pontic Sigillata Plates with a Vertical Rim from the Belbek IV Necropolis in the South-Western Crimea", Ancient Civilizations Scythia in Siberia 15: 2529. 



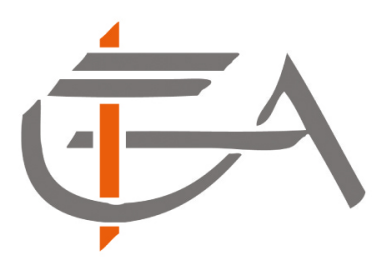

Institut Français

d'Etudes Anatoliennes

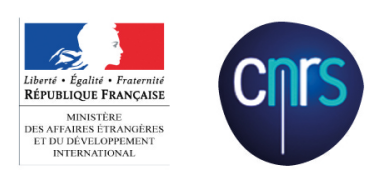

Peinture rupestre préhistorique, Sağlık Köy, près d'Alabanda, Turquie (cliché Suat Ateşlier). 